\title{
Tools for Evaluating Native Grasses as Low Maintenance Turf
}

\author{
Landon D. Bunderson ${ }^{1}$, Paul G. Johnson ${ }^{2,3}$, Kelly L. Kopp ${ }^{2}$, \\ and Adam Van Dyke ${ }^{2}$
}

ADDITIONAL INDEX WORDs. digital image analysis, chlorophyll meter, point-quadrat, DGCI, dark green color index

SUMMARY. Visual ratings are the standard for evaluating turfgrass quality. However, to provide more objective evaluations and to address statistical concerns, other methods have been developed to measure turfgrass quality, including digital image analysis and measurements of chlorophyll content. These have been largely applied to traditionally used turfgrass species, but here we used these methods to evaluate turfgrass quality of nontraditional species and mixtures that are native or adapted to the intermountain west region of North America. Two fertilizer treatments $(1.0$ or $2.0 \mathrm{lb} / 1000 \mathrm{ft}^{2}$ nitrogen) were applied to 21 different species and species mixtures in North Logan, UT. These plots were irrigated to replace $60 \%$ of the local evapotranspiration rate and were mowed at 4 inches. Turfgrass quality ratings were most effective in measuring quality among the diverse species used in this study. Because of the wider variation in acceptable visual characteristics and lower quality expectations for low-maintenance native turf, the objective evaluation methods proved less useful. Generally, chlorophyll meter data, digital image analysis of cover, and digital image analysis of color data were not well correlated with human visual quality ratings in this study. Measurements were well correlated in some species, but not in others. These methods can supplement, but cannot replace, human visual turfgrass quality ratings for comparison of dissimilar grasses.

$\mathrm{E}$ valuating aesthetic qualities of turfgrass can be difficult because quality is not measured quantitatively, but is measured subjectively by visual estimation (Skogley and Sawyer, 1992). This human-based visual evaluation attempts to incorporate all of the attributes of aesthetic quality into one rating (Morris, 2001). Visual quality ratings made by trained evaluators are made on a 1 to 9 scale, where 1 indicates dormant or dead grass and 9 indicates the highest quality (Skogley and Sawyer, 1992). Turf quality is most influenced by the color and uniformity of a turfgrass stand, but leaf density, texture, growth habit, and smoothness of the turf also factor into the ratings (Turgeon, 2002). Although visual quality ratings are effective for comparisons,

\footnotetext{
This research was supported by the Utah Agricultural Experiment Station (Logan, UT), Utah State University (Logan, UT), The Center for Water Efficient Landscaping (Logan, UT), and the Utah Botanical Center (Kaysville, UT).

Approved as UAES Journal Paper number 7978.

${ }^{1}$ Biograss Sod, Inc., Sandy, UT 84070.

${ }^{2}$ Department of Plants, Soils, and Climate, Utah State University, Logan, UT 84322.

${ }^{3}$ Corresponding author. E-mail: paul.johnson@usu.edu.
}

these data can be highly variable, difficult to repeat, and affected by the evaluator (Horst et al., 1984), and statistical analysis using analysis of variance is sometimes debated (Karcher, 2000). These are the reasons why methods have been developed to quantitatively measure turfgrass quality (Karcher and Richardson, 2003).

Digital image analysis and chlorophyll meter measurements have been effective to describe color, chlorophyll content, and/or cover of a turfgrass stand (Karcher and Richardson, 2003; Landschoot and Mancino, 2000; Richardson et al., 2001). These methods have also been used for detecting nitrogen (N) content differences (Karcher and Richardson, 2003; Landschoot and Mancino, 2000) and evaluating plant responses (Klassen et al., 2003). However, these techniques have been mostly used on uniform stands of turfgrass such as mowed kentucky bluegrass (Poa pratensis), creeping bentgrass (Agrostis stolonifera), and bermudagrass (Cynodon dactylon). These methods have not been used for evaluating stands of native grasses with variable visual characteristics. The color of native turfgrass stands vary widely, making comparisons of turfgrass quality difficult. This is a challenge in the development of new species for naturalized turf areas.

To determine which quality evaluation techniques are most useful and informative when applied to native grasses, we evaluated human-based visual ratings and objective (instrument-based) measurements in comparing turfgrass quality traits, specifically color and density of the stand.

\section{Materials and methods}

Plot Design. Monostands and mixtures of grasses native and adapted to the intermountain west region of North America were grown as turf (Table 1) and evaluated for greenness, visual appeal, and percentage of cover at the end of each month from May to October in 2005 and 2006. The experimental design was a splitplot with four replications of each grass monostand or mixture (whole plot factor) planted in a $6-\times 40-\mathrm{ft}$ plot at the Utah Agricultural Experiment Station's Greenville Research Farm in North Logan on a Millville silt loam (coarse-silty mesic Typic Haploexeroll) at $\mathrm{pH}$ 7.9. Two fertilizer treatments were randomly assigned and applied to one-half of each monoculture or mixture (subplot) at 1.0 or $2.0 / 1000 \mathrm{ft}^{2} \mathrm{~N}$. Urea $(46 \mathrm{~N}-0 \mathrm{P}-0 \mathrm{~K})$ was applied at $1.0 \mathrm{lb} / 1000 \mathrm{ft}^{2} \mathrm{~N}$ to the whole experiment in the fall, and half of each plot received a second treatment of urea at $1.0 \mathrm{lb} / 1000 \mathrm{ft}^{2}$ in late spring. Irrigation was applied every $6 \mathrm{~d}$ to replace $60 \%$ of reference evapotranspiration $\left(\mathrm{ET}_{\mathrm{o}}\right)$ (Allen et al., 1998). Grasses were mowed at 4 inches once per week.

\begin{tabular}{llll}
\hline $\begin{array}{l}\text { Units } \\
\begin{array}{l}\text { To convert U.S. to SI, } \\
\text { multiply by }\end{array}\end{array}$ & U.S. unit & SI unit & $\begin{array}{l}\text { To convert SI to U.S., } \\
\text { multiply by }\end{array}$ \\
\hline 0.3048 & $\mathrm{ft}$ & $\mathrm{m}$ & 3.2808 \\
2.54 & inch $(\mathrm{es})$ & $\mathrm{cm}$ & 0.3937 \\
48.8243 & $\mathrm{lb} / 1000 \mathrm{ft}^{2}$ & $\mathrm{~kg} \cdot \mathrm{ha}^{-1}$ & 0.0205 \\
1.1209 & $\mathrm{lb} / \mathrm{acre}$ & $\mathrm{kg} \cdot \mathrm{ha}^{-1}$ & 0.8922
\end{tabular}


Table 1. Grass species, species mixtures, and seeding rates of native and well-adapted grasses evaluated in North Logan, UT.

Species 1 Species 2 Species 3

Species and mixtures $\left[\operatorname{seed~}\left(\mathrm{kg} \cdot \mathrm{ha}^{-1}\right)\right]^{\mathrm{z}}$

'Cody' buffalograss (Buchloë dactyloides) 98

'Foothills' canada bluegrass ( Poa compressa) 98

'Bad River' blue grama (Bouteloua gracilis) 98

'RoadCrest' crested wheatgrass (Agropyron cristatum) 294

'Sodar' streambank wheatgrass (Elymus lanceolatus) 294

'Rosana' western wheatgrass (Pascopyrum smithii) 294

'Critana' thickspike wheatgrass (Elymus lanceolatus) 294

Muttongrass (Poa fendleriana)

'Covar' sheep fescue (Festuca ovina)

294

'Triple play blend' tall fescue (Festuca arundinacea) ${ }^{\mathrm{y}} \quad 294$

'Brilliant' kentucky bluegrass (Poa pratensis)

Buffalograss + blue grama

49

Buffalograss + muttongrass

Buffalograss + sheep fescue

Buffalograss + blue grama + muttongrass

Buffalograss + western wheatgrass

Blue grama + western wheatgrass

98

98

Western wheatgrass + streambank

wheatgrass + sheep fescue

\section{8}

147

Western wheatgrass + streambank wheatgrass

49

Canada bluegrass + western wheatgrass

l $\mathrm{kg} \cdot \mathrm{ha}^{-1}=0.8922 \mathrm{lb} /$ acre

'Triple play blend consists of 34\% 'Montauk', 33\% 'Wildcat', and 33\% 'Heritage' tall fescue cultivars.

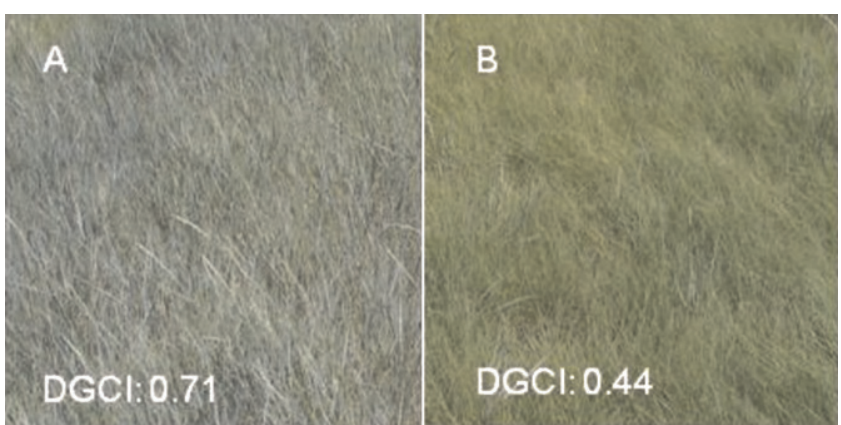

Fig. 1. Western wheatgrass (A) and blue grama (B) exhibited similar and acceptable visual quality ratings ( $1-9$ scale: 1 = worst, 9 = best, 5 = acceptable), but exhibited very different dark green color index (DGCI) values ( $0-1.0$; with $1=$ darkest green ) as measured by digital image analysis of color. This emphasized that the presence of green cover is most important in native grass turfs and that the shade of green is secondary.

VisUAL QUALITY RATINGS. Visual quality ratings were made by one person throughout the experiment (Morris, 2001). A rating of 9 was assigned to the best plot for the evaluation date and a 5 to 6 was considered minimally acceptable for a low-maintenance turf setting. One shade of green was not favored, or given a higher rating, over another. For example, a bright green color was not rated higher than a blue-green color. Light green colors, or yellow-
Richardson, 2005). Photographs using a resolution of 307,200 pixels $(640 \times 480)$ were taken in full sun, between 1000 and $1400 \mathrm{HR}, \approx 4 \mathrm{ft}$ above the ground. At this height, the field of view was $\approx 3 \times 4 \mathrm{ft}$. The digital image analysis of cover calculated the percentage of green cover by selecting pixels that were within threshold values (green grass) and divided by the total number of pixels in the photograph. The digital image analysis of color, or measure of greenness, evaluated the shades of green in the stand. The dark green color index (DGCI) was calculated using red, green, blue, hue, saturation, and brightness data as calculated by the "Turf Analysis" macro (Karcher and Richardson, 2005 ) and Sigma Scan ${ }^{\circledR}$.

In digital analysis of cover and color, small areas of the plot were sampled by the photographs relative to the much larger plot size. In 2005 , one photo was taken per plot, but the visual rating was done on the same location in the plot. In 2006, three photos were taken to represent the plot as a whole, and as in 2005 , the visual quality was rated on about the same locations within the plot to reduce potential variation between ratings and digital measurements.

Chlorophyll Meter. Greenness was also monitored monthly using a chlorophyll meter (Field Scout CM 1000; Spectrum Technologies, Inc., Plainfield, IL), which measured ratios of reflected red and far-red light to calculate relative chlorophyll content, or greenness. Three measurements were taken within each plot with the sun at the operator's back from 1000 to 1400 $\mathrm{HR}$ at $4 \mathrm{ft}$ above the ground. This assessed a $4.5-\mathrm{cm}$-diameter circle of grass. The output is a unitless index of chlorophyll content on a scale of 0 to 999.

Statistical analysis. The data in this experiment were analyzed using PROC MIXED repeated measures analysis and PROC CORR in SAS (version 9.1; SAS Institute, Cary, NC). Species/mixture, N, and observation date were fixed variables, and replication was a random variable. The analysis was repeated by observation date. Treatment means were compared using least-squared means, and correlation analysis was also performed among measurement methods. 


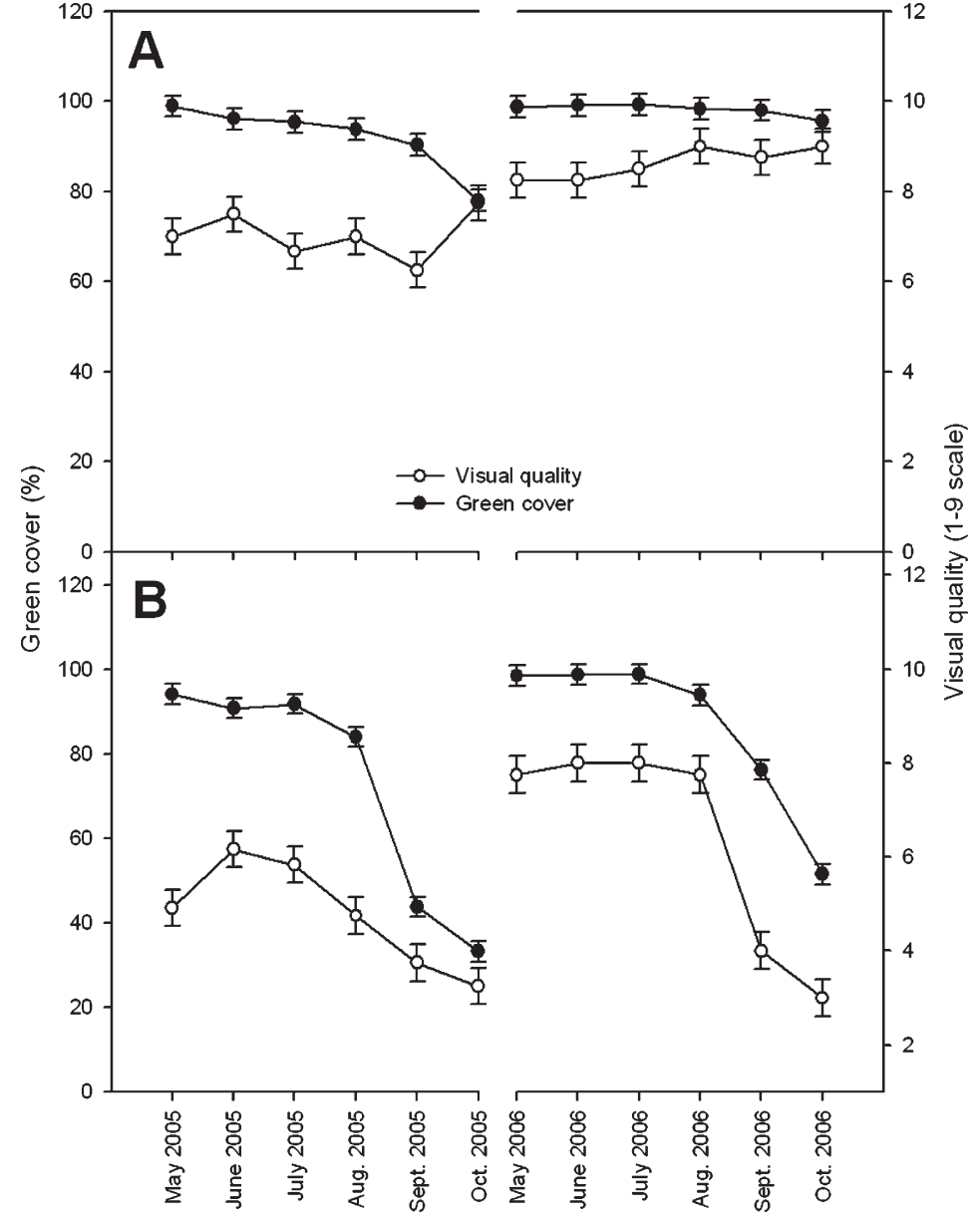

Fig. 2. Visual turfgrass quality ( $1-9$ scale: $1=$ worst, $9=$ best, $5=$ acceptable), a qualitative measure of dense green cover, was associated with the percentage of green cover as measured by digital image analysis in sheep fescue (A) and blue grama (B). These two types of data showed similar trends during most of 2005 and 2006. Error bars represent standard error of the mean.

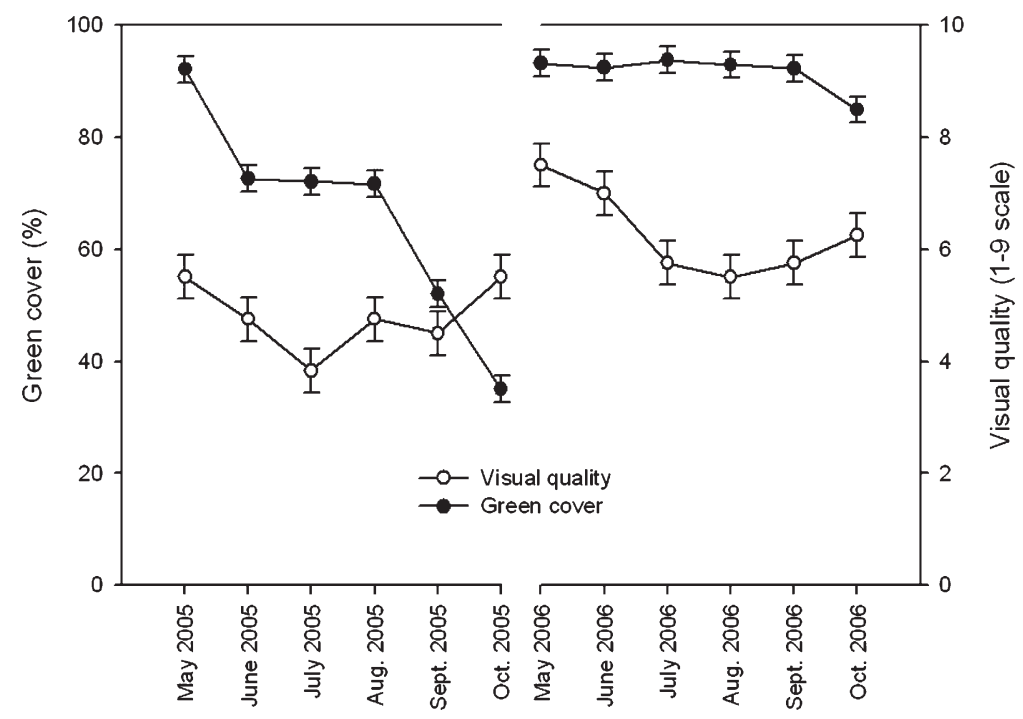

Fig. 3. Leaf blade shredding in streambank wheatgrass caused by mowing, resulted in brown leaf tips and reduced turfgrass quality ( $1-9$ scale: $1=$ worst, $9=$ best, 5 = acceptable) by detracting from the green color of the leaves during summer months of both years, but especially in 2005 . This reduction in quality was not reflected in similar reductions in the percentage of green cover as measured by digital image analysis of cover. Error bars represent standard error of the mean.

\section{Results and discussion}

Visual RATING. The plots in this experiment varied tremendously in color, texture, and growth habit among the different species and mixtures. Genetic color varied from bluegreen to dark green to gray-green. Although the soil $\mathrm{pH}$ of 7.9 is relatively high, nutrient deficiencies caused by these conditions were not observed in these experimental plots. Western wheatgrass (Pascopyrum smithii) and blue grama (Bouteloua gracilis) were adequately dense and had the color of actively growing grass [i.e., green color appropriate for the species (Fig. 1)]. Density and the presence of green color were the most influential factors in this rating, therefore, visual ratings were very similar (Bunderson, 2007). Another factor that influenced visual ratings was dormancy during some part of the growing season (Fig. 2). Warm-season grasses such as blue grama were dormant in spring and fall, while some of the cool-season grasses were dormant in the summer. Green cover also varied widely among the stands (Bunderson, 2007).

Digital image anAlysis of COVER. Digital image analysis of cover yielded similar results as the visual quality ratings in some species and mixtures in this study. As described above, grasses varied widely in green cover percentages as the season progressed. Because digital image analysis of cover could not distinguish between soil and senesced or dormant leaves in our study, this method was not a good representation of total plant cover but rather green cover, the characteristic that is most heavily weighted in visual quality ratings. For example, digital image analysis of cover for blue grama was high in the late spring and summer and low in the fall-a trend that followed the visual quality ratings (Fig. 2). Sheep fescue (Festuca ovina) exhibited consistently high digital image analysis of cover (with the exception of Oct. 2005) and acceptable visual quality (Fig. 2). The correlation of visual ratings and digital image analysis of cover among all plots was significant $(P<0.0001)$ with an $\mathrm{r}^{2}$ of 0.51 over both years, but digital cover analysis was not a satisfactory predictor of quality. This is discussed in greater detail in the "Comparison of Methods" section. 
The relationship of digital image analysis of cover and visual quality was quite different in the case of muttongrass (Poa fendleriana) where digital

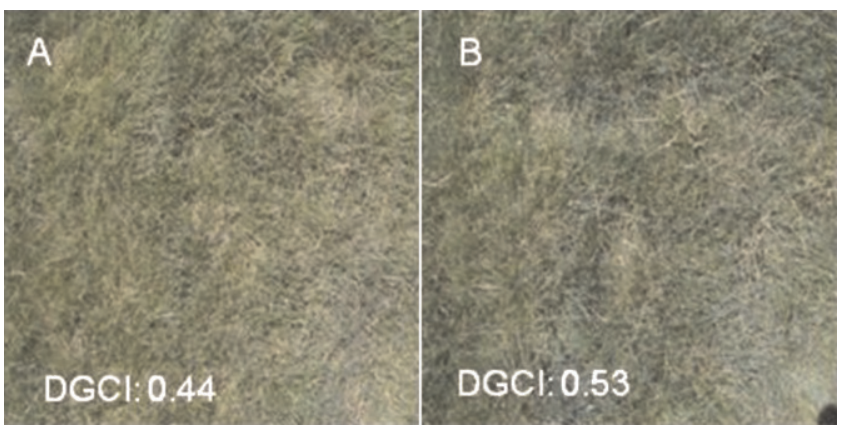

Fig. 4. Nitrogen fertilization at (A) $1.0 \mathrm{lb} / 1000 \mathrm{ft}^{2}\left(48.82 \mathrm{~kg} \cdot \mathrm{ha}^{-1}\right) \mathrm{N}$ and (B) 2.0 $\mathrm{lb} / 1000 \mathrm{ft}^{2}\left(97.65 \mathrm{~kg} \cdot \mathrm{ha}^{-1}\right) \mathrm{N}$ significantly influenced color of the plots as measured by digital image analysis of color and calculation of the dark green color index (DGCI) (0-1.0: 1.0 = darkest green). Plots shown in these photographs are of sheep fescue. $1.0 \mathrm{lb} / 1000 \mathrm{ft}^{2}=48.8243 \mathrm{~kg} \cdot \mathrm{ha}^{-1}$. the weeds, poor turf quality, and sparseness of the stand (data not shown). Weeds must be noted or removed from the photograph to get accurate data representing the intended species.

Streambank wheatgrass (Elymus lanceolatus) received high (>70\%) digital image analysis of cover percentages early in 2005 and all months in 2006, but visual quality (ratings of 4-5) was low in Summer 2005 and marginally acceptable $(5.8-6.0)$ in Summer 2006 (Fig. 3). Streambank wheatgrass was dormant in Summer 2005 , resulting in reduced green cover and visual quality. In 2005 , the lack of green cover and leaf blade shredding, caused by mowing (Johnson 2008), decreased visual quality. In 2006, streambank wheatgrass remained more actively growing,
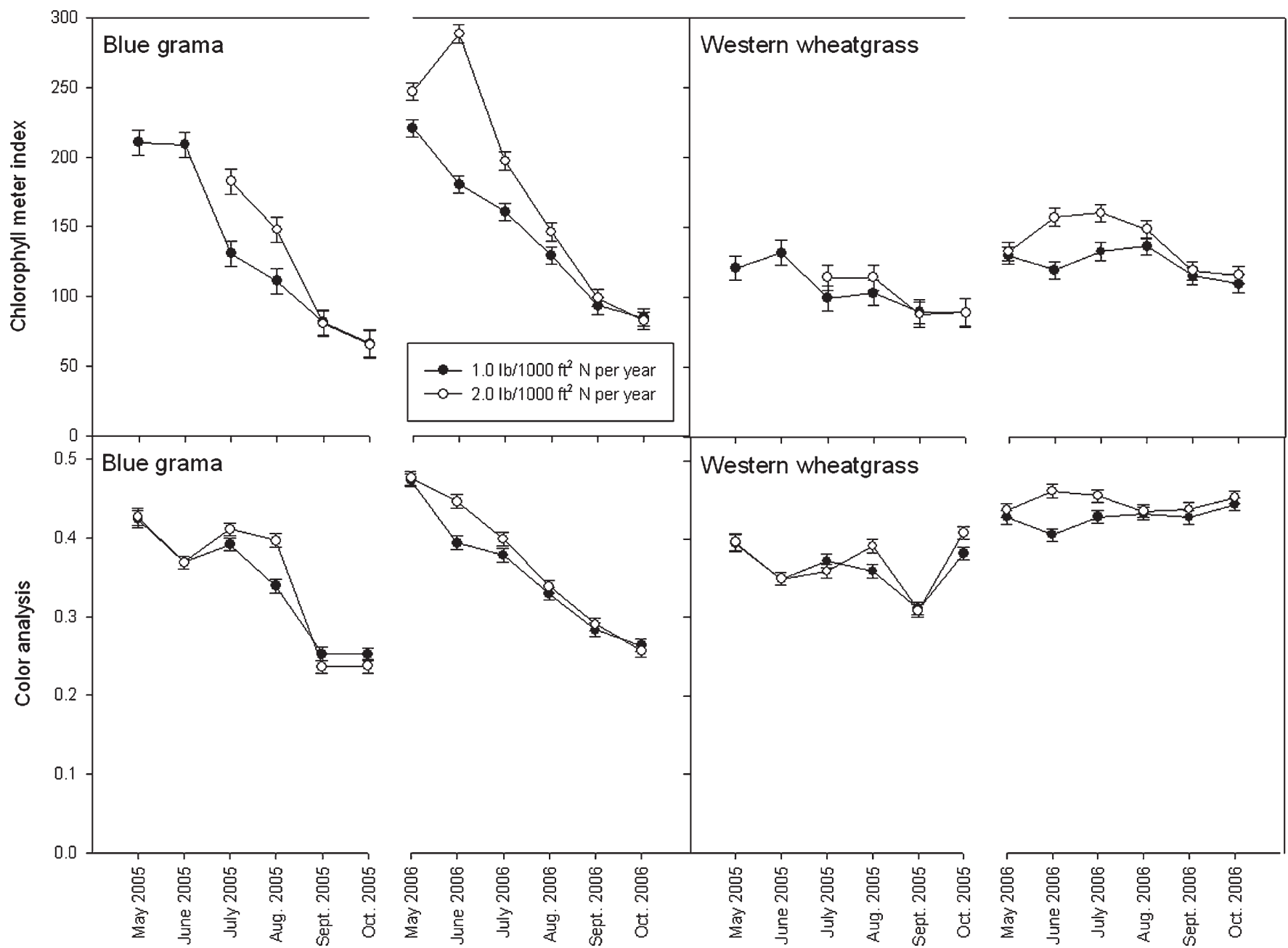

Fig. 5. Chlorophyll meter measurements (0-999 scale: higher numbers mean darker green plots) showed similar trends as dark green color index values (DGCI) (0-1.0: $1.0=$ darkest green) as measured by digital image analysis of color in blue grama and western wheatgrass at $1.0 \mathrm{lb} / 1000 \mathrm{ft}^{2}\left(48.82 \mathrm{~kg} \cdot \mathrm{ha}^{-1}\right) \mathrm{N}$ and $2.0 \mathrm{lb} / 1000 \mathrm{ft}^{2}\left(97.65 \mathrm{~kg} \cdot \mathrm{ha}^{-1}\right) \mathrm{N}$ fertilization levels in 2005 and 2006. Error bars represent standard error of the mean. $1.0 \mathrm{lb} / 1000 \mathrm{ft}^{2}=48.8243 \mathrm{~kg} \cdot \mathrm{ha}^{-1}$. 


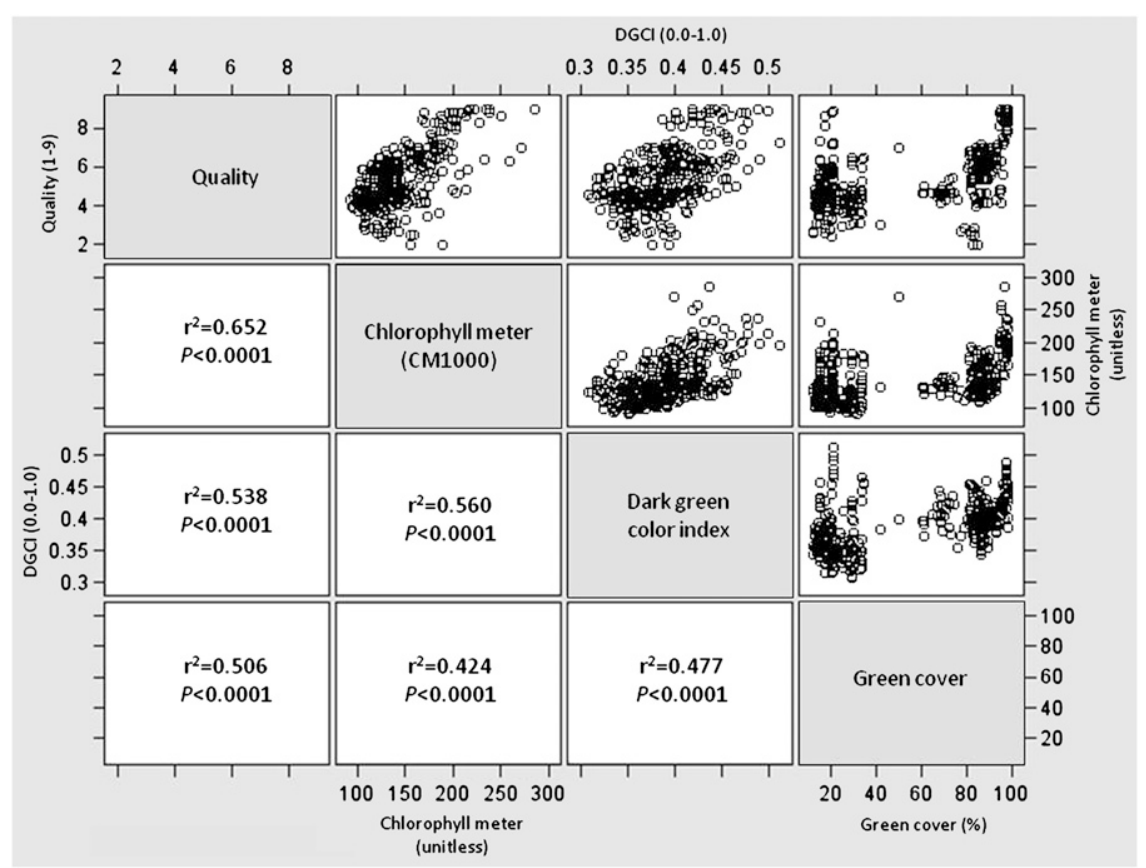

Fig. 6. A scatter plot matrix shows the relationship of measurement techniques combining all species and mixtures (see Table 1 for listing) and $\mathrm{N}$ fertilization levels $\left[1.0 \mathrm{lb} / 1000 \mathrm{ft}^{2}\left(48.82 \mathrm{~kg} \cdot \mathrm{ha}^{-1}\right) \mathrm{N}\right.$ and $\left.2.0 \mathrm{lb} / 1000 \mathrm{ft}^{2}\left(97.65 \mathrm{~kg} \cdot \mathrm{ha} \mathrm{a}^{-1}\right) \mathrm{N}\right]$ and two years (2005 and 2006). Correlation coefficients $\left(r^{2}\right)$ and correlation significance $(P$ value $)$ are shown for each measurement comparison in the lower half of the matrix. The measurements compared are visual quality $(1-9$ scale: $1=$ worst, $9=$ best, $5=$ acceptable), chlorophyll meter (0-999 scale: higher numbers mean darker green plots) (CM 1000; Spectrum Technologies, Inc., Plainfield, IL), dark green color index (DGCI) as measured by digital analysis of color $(0-1.0: 1.0=$ darkest green), and the percentage of green cover as measured by digital analysis. $1.0 \mathrm{lb} / 1000 \mathrm{ft}^{2}=48.8243 \mathrm{~kg} \cdot \mathrm{ha}^{-1}$.

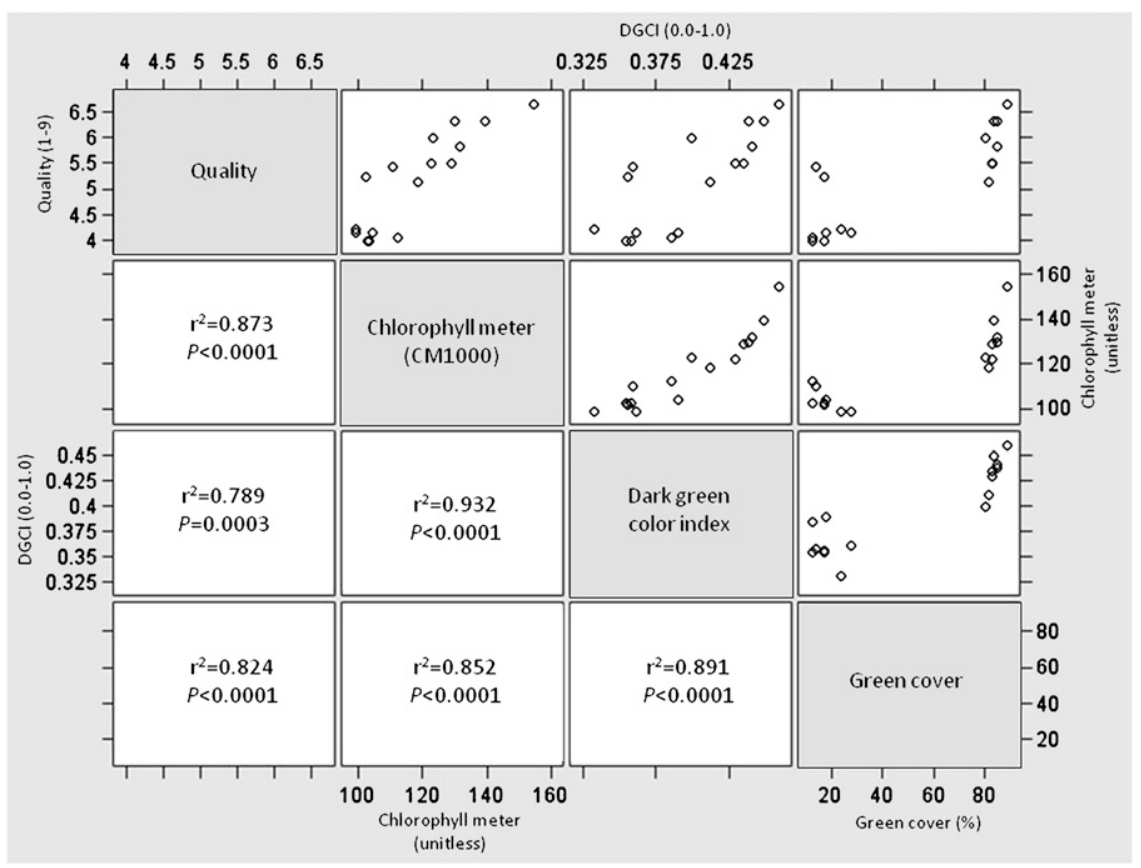

Fig. 7. A scatter plot matrix shows the relationship of measurement techniques for western wheatgrass plots over two $\mathrm{N}$ fertilization levels $\left[1.0 \mathrm{lb} / 1000 \mathrm{ft}^{2}\left(48.82 \mathrm{~kg} \cdot \mathrm{ha}^{-1}\right) \mathrm{N}\right.$ and $\left.2.0 \mathrm{lb} / 1000 \mathrm{ft}^{2}\left(97.65 \mathrm{~kg} \cdot \mathrm{ha}^{-1}\right) \mathrm{N}\right]$ and two years $(2005$ and 2006$)$. Correlation coefficients $\left(r^{2}\right)$ and correlation significance $(P$ value) are shown for each measurement comparison in the lower half of the matrix. The measurements compared are visual quality ( $1-9$ scale: 1 = worst, $9=$ best, $5=$ acceptable), chlorophyll meter (0-999 scale: higher numbers mean darker green plots) (CM 1000; Spectrum Technologies, Inc., Plainfield, IL), dark green color index (DGCI) as measured by digital analysis of color (0-1.0: 1.0 = darkest green), and the percentage of green cover as measured by digital analysis. $1.0 \mathrm{lb} / 1000 \mathrm{ft}^{2}=48.8243 \mathrm{~kg} \cdot \mathrm{ha}^{-1}$. 


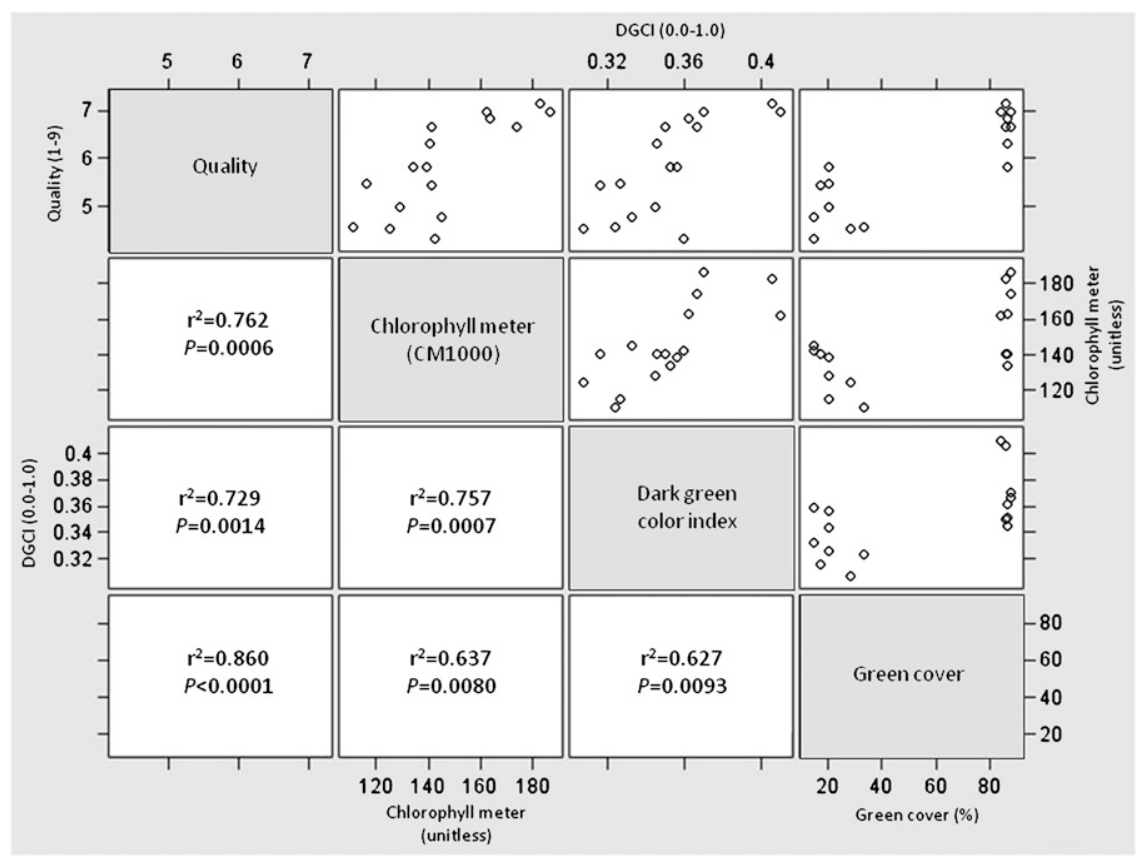

Fig. 8. A scatter plot matrix shows the relationship of measurement techniques for blue grama plots over two $\mathbf{N}$ fertilization levels $\left[1.0 \mathrm{lb} / 1000 \mathrm{ft}^{2}\left(48.82 \mathrm{~kg} \cdot \mathrm{ha}^{-1}\right) \mathrm{N}\right.$ and $2.0 \mathrm{lb} / 1000 \mathrm{ft}^{2}\left(97.65 \mathrm{~kg} \cdot \mathrm{ha}^{-1}\right) \mathrm{N}$ ] and two years $(2005$ and 2006$)$. Correlation coefficients $\left(\mathbf{r}^{2}\right)$ and correlation significance $(P$ value) are shown for each measurement comparison in the lower half of the matrix. The measurements compared are visual quality ( $1-9$ scale: 1 = worst, 9 = best, 5 = acceptable), chlorophyll meter (0-999 scale: higher numbers mean darker green plots) (CM 1000; Spectrum Technologies, Inc., Plainfield, IL), dark green color index (DGCI) as measured by digital analysis of color (0-1.0: 1.0 = darkest green), and the percentage of green cover as measured by digital analysis. $1.0 \mathrm{lb} / 1000 \mathrm{ft}^{2}=48.8243 \mathrm{~kg} \cdot \mathrm{ha}^{-1}$.

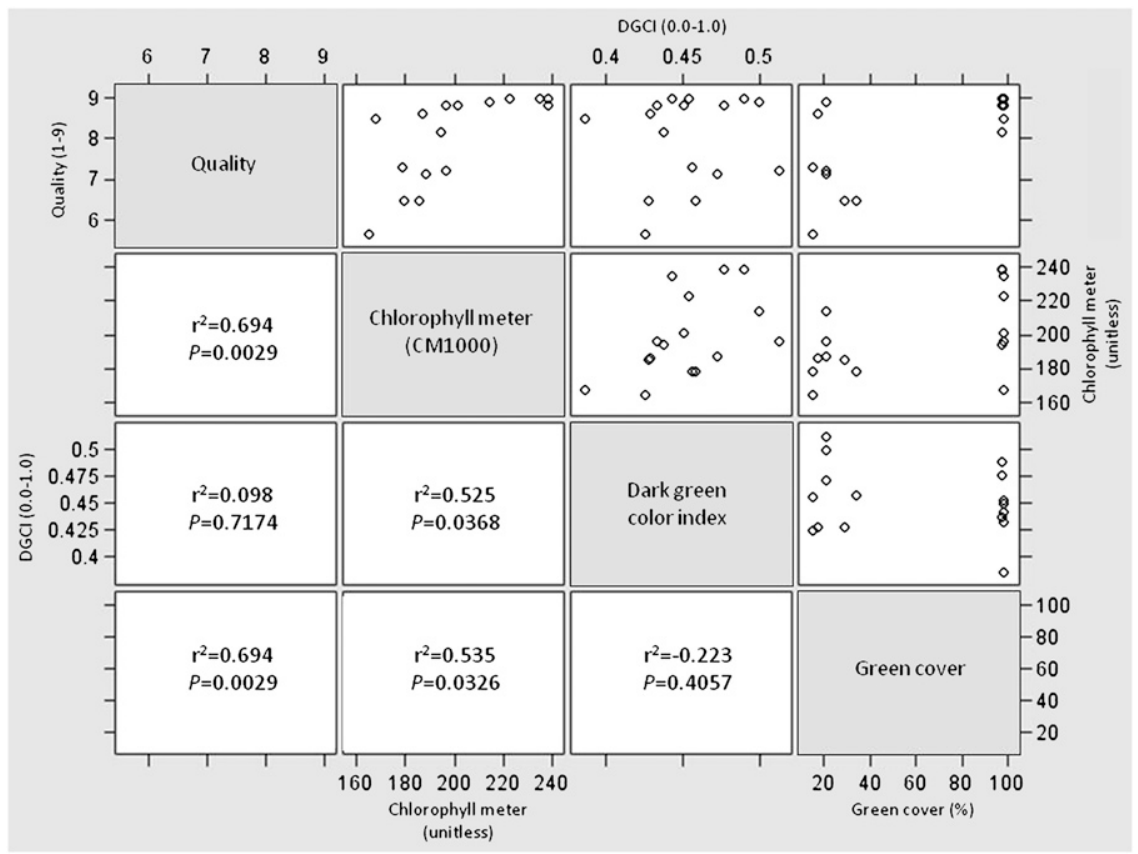

Fig. 9. A scatter plot matrix shows the relationship of measurement techniques for sheep fescue plots over two $\mathrm{N}$ fertilization levels $\left[1.0 \mathrm{lb} / 1000 \mathrm{ft}^{2}\left(48.82 \mathrm{~kg} \cdot \mathrm{ha}^{-1}\right) \mathrm{N}\right.$ and $2.0 \mathrm{lb} / 1000 \mathrm{ft}^{2}\left(97.65 \mathrm{~kg} \cdot \mathrm{ha}^{-1}\right) \mathrm{N}$ ] and two years $(2005$ and 2006$)$. Correlation coefficients $\left(r^{2}\right)$ and correlation significance $(P$ value $)$ are shown for each measurement comparison in the lower half of the matrix. The measurements compared are visual quality (1-9 scale: 1 = worst, 9 = best, 5 = acceptable), chlorophyll meter (0-999 scale: higher numbers mean darker green plots) (CM 1000; Spectrum Technologies, Inc., Plainfield, IL), dark green color index (DGCI) as measured by digital analysis of color (0-1.0: 1.0 = darkest green), and the percentage of green cover as measured by digital analysis. $1.0 \mathrm{lb} / 1000 \mathrm{ft}^{2}=48.8243 \mathrm{~kg} \cdot \mathrm{ha}^{-1}$. 
exhibiting near complete green cover for most of the year (Fig. 3), but had relatively low visual quality due to leaf blade shredding.

Digital image analysis of COLOR. Green color hue was not as important as green cover in determining turfgrass quality, therefore digital image analysis of color was not an effective tool in comparing turfgrass quality in this study. As mentioned previously, some entries in the study had similar and relatively high-quality ratings but very different DGCI values. Western wheatgrass is blue-gray-green in color with a DGCI value of 0.71 , while the more yellow-green blue grama had a DGCI of 0.44 (Fig. 1).

The digital image analysis of color was effective in distinguishing greenness differences of $\mathrm{N}$ treatments within a species or a mixture (Figs. 4 and 5; Bunderson, 2007) and as reported previously by Mangiafico and Guillard (2005). For more accurate color evaluations, digital image analysis of color should use controlled conditions, such as an enclosed box with artificial lighting. Color of the turfgrass leaves are affected by incident light, reducing the ability to effectively compare treatments at different times of the day, days of the year, or other atmospheric factors (Ikemura, 2003).

Chlorophyll meter. The chlorophyll meter measured greenness and gave a value representing color only, yielding similar results to the digital image analysis of color (Fig. 5). However, the chlorophyll meter had the advantage of allowing the user to aim the meter toward plot locations so that weeds could be avoided. As in digital image analysis of color, the chlorophyll meter often detected differences in $\mathrm{N}$ treatments (Fig. 5).

COMPARISON OF METHODs. Correlations between measurements were significant but highly variable across all the species and mixtures, but in terms of using one measurement to predict visual quality, none were satisfactory overall (Fig. 6). For some species, such as western wheatgrass, some measurements were well correlated, allowing the chlorophyll meter to predict quality (Fig. 7). For other species, such as blue grama, the relationships were significant but of poor predictive value (Fig. 8). For most species and mixtures, including sheep fescue (Fig. 9) and canada bluegrass (data not shown), correlations were poor and of no predictive value.

\section{Conclusion}

We evaluated the use of humanbased (i.e., visual) and instrumentbased methods of evaluating turfgrass quality on turfgrasses native and adapted to the intermountain west region of North America. Visual turfgrass quality ratings proved effective in measuring a diverse set of criteria in turfgrass plantings; however, because of the wider variation in visual characteristics and expectations of low-maintenance or nontraditional species, digitally based methods of evaluation were less useful by themselves. Generally, chlorophyll meter data and digital image analysis using currently available technology were not well correlated with visual quality ratings in this study. The chlorophyll meter proved more effective than the digital image analysis of color in this experiment because it allowed the operator to easily point the meter away from bare ground and weeds. These instrument-based methods can provide supplementary information for turfgrass evaluation especially when comparing management treatment effects within a species, but cannot replace visual turfgrass quality ratings for comparison of dissimilar grasses.

\section{Literature cited}

Allen, R.G., L.S. Pereira, D. Raes, and M. Smith. 1998. Crop evapotranspiration: Guidelines for computing crop water requirements. Food Agr. Organization (FAO) Irr. Drainage Paper 56.

Bunderson, L.D. 2007. Evaluation of native and adapted grass species and their management for turfgrass applications in the intermountain west. Utah State University, Logan, Master's thesis.

Horst, G.L., M.C. Engelke, and W. Meyers. 1984. Assessment of visual evaluation techniques. Agron. J. 76:619-622.

Ikemura, Y. 2003. Using digital image analysis to measure the nitrogen concen- tration of turfgrasses. University of Arkansas, Fayetteville, Master's thesis.

Johnson, P.G. 2008. Native grasses as drought-tolerant turfgrasses of the future, p. 619-640. In: M. Pessarakli (ed.). Handbook of turfgrass management and physiology. CRC Press, Boca Raton, FL.

Karcher, D.E. 2000. Investigations on statistical analysis of turfgrass rating data, localized dry spots of greens, and nitrogen application techniques for turf. Michigan State University, East Lansing, PhD Diss.

Karcher, D.E. and M.D. Richardson. 2003. Quantifying turfgrass color using digital image analysis. Crop Sci. 43:943951 .

Karcher, D.E. and M.D. Richardson. 2005. Batch analysis of digital images to evaluate turfgrass characteristics. Crop Sci. 45:1536-1539.

Klassen, S.P., G.L. Ritchie, J.M. Frantz, D.R. Pinnock, and B. Bugbee. 2003. Real-time imaging of ground cover: Relationships with radiation capture, canopy photosynthesis, and daily growth rate, $\mathrm{p}$. 3-14. In: T. Van Toai, D. Major, M. McDonald, J. Schepers, and L. Tarpley (eds.). Digital imaging and spectral techniques: Applications to precision agriculture and crop physiology. ASA Spec. Publ. 66. Amer. Soc. Agron., Crop Sci. Soc. Amer., Soil Sci. Soc. Amer., Madison, WI.

Landschoot, P.J. and C.F. Mancino. 2000. A comparison of visual vs. instrumental measurement of color differences in bentgrass turf. HortScience 35:914916.

Mangiafico, S.S. and K. Guillard. 2005. Turfgrass reflectance measurements, chlorophyll, and soil nitrate desorbed from anion exchange membranes. Crop Sci. 45:259-265.

Morris, K.N. 2001. A guide to NTEP turfgrass ratings. 11 Nov. 2008. <http:// www.ntep.org/reports/ratings.htm>.

Richardson, M.D., D.E. Karcher, and L.C. Prucell. 2001. Quantifying turfgrass cover using digital image analysis. Crop Sci. 41:1884-1888.

Skogley, C.R. and C.D. Sawyer. 1992. Field research, p. 589-614. In: D.V. Waddington, R.N. Carrow, and R.C. Shearman (eds.). Turfgrass. Amer. Soc. Agron., Madison, WI.

Turgeon, A.J. 2002. Turfgrass management, 6th ed. Prentice Hall, Upper Saddle River, NJ. 